\title{
Rio 1992: \\ Hvad har det ført til?
}

\section{Jørgen Henningsen}

\section{Rio-topmødet i 1992 var en skelsættende begiven- hed. Aldrig før havde så mange af Verdens ledere været samlet om et og samme formål, og så endda et så respektabelt formål som Verdens frelse}

Rio-konferencen var verdenssamfundets forsøg på at omsætte Brundtland-kommissionens rapport om bæredygtig udvikling til politisk virkelighed, og betingelserne var, relativt set, gunstige: den kolde krig var afviklet, og erkendelsen af behovet for at sætte miljøbeskyttelse på dagsordenen havde i de foregående år bredt sig til langt flere lande end den lille kreds af 'frelste' efter Stockholm-konferencen 20 år tidligere. Ikke mindst i Europa var ambitionerne høje.

Det er ingen enkel sag at gøre status over, hvordan det så efterfølgende er gået. Men hvis man skal sammenfatte vurderingen i et enkelt ord, kan det kun blive 'skuffende'. Og hvis man skal sammenfatte det $\mathrm{i}$ to ord, må det blive 'rigtig skuffende'. Denne vurdering er ikke bare et udtryk for, at de mål, der mere eller mindre præcist blev formuleret $\mathrm{i}$ Rio, ikke er blevet opfyldt; det er nok så meget et udtryk for, at de processer, der skulle føre til målene, enten slet ikke kom i gang, eller begyndte i alt for lavt tempo for så ofte at gå i stå.

Rio-konferencen afleverede tre hoveddokumenter til eftertiden: En Klimakonvention (UNFCCC), en Biodiversitetskonvention (CBD) og den såkaldte Agenda-21, et dokument, der forsøger at anvise vejen til bæredygtig udvikling i samfundets forskellige sektorer, herunder også i lokalsamfundene. Ud over disse vedtog konferencen en deklaration om skove og knæsatte diverse principper for det globale miljøarbejde, herunder forsigtighedsprincippet: at det kan være nødvendigt at træffe beslutninger om miljøbeskyttelse, selv om det videnskabelige grundlag 
ikke er 100 procent afklaret; et princip, de fleste af os praktiserer i mange daglige situationer, men som desværre ikke nødvendigvis er slået fuldt igennem i fx klimapolitikken. Tilsvarende var det Rio-konferencen der lancerede princippet om borgernes ret til at få miljøspørgsmål indbragt for de nationale retsvæsener, et princip der senere ledte til Århus-konventionen.

\section{Den globale klimapolitik}

Klimakonventionen har i virkeligheden betydelig større kvaliteter, end hvad den har fået kredit for. I erkendelse af at det ikke havde været muligt at få en mere detaljeret klimaaftale på plads i de 16 måneder, forhandlingspartnerne havde til rådighed, indeholder konventionen en bestemmelse om, at den første partskonference skulle tage stilling til tilstrækkeligheden af konventionens konkrete forpligtelser. Det tog ikke lang tid i 1995 at nå til enighed om, at der skulle mere til. Det tog længere tid, 31 måneder, at nå til enighed om resultatet, Kyoto-protokollen (KP), og desværre førte KP-processen til, at UNFCCC, der i virkeligheden er et stærkere klimapolitisk instrument end KP, blev lagt til side. Helt galt gik det, da præsident Bush i 2001 meldte USA ud af KP. I realiteten er Kyoto-protokollen takket været muligheden for emissionshandel mellem parterne (ikke at forveksle med EU's kvotehandelssystem) en kollektiv forpligtelse mellem de parter, der har påtaget sig kvantitative reduktionsmål. Uden USA's deltagelse har de resterende parter så store mængder 'varm luft' (emissionsmuligheder de pågældende lande ikke har brug for) til disposition, at alle resterende parter kan klare deres KP-forpligtelser ved rent papirarbejde. Canada havde egentlig slet ikke haft brug for at melde sig ud, som det skete i december 2011.

Det er tankevækkende at konstatere, at Kyoto-protokollen har kunnet opretholde sin prestige blandt dem, der hævder at kæmpe for en bedre klimapolitik. Der har ikke på noget tidspunkt siden 2001 været den ringeste udsigt til, at KP ville levere noget af værdi til klimabeskyttelsen, hverken i den vedtagne periode (2008-12) eller senere. Den altafgørende barriere er den amerikanske forfatning, der kræver to tredjedels flertal i Senatet for ratifikation af en aftale af 'Kyoto-karakter', et flertal som ingen realistisk kan forestille sig.

Den triste konklusion er, at hvor det måske kan betyde noget for intern amerikansk klimapolitik, hvad den siddende præsident mener, er det til gengæld uden betydning for USA's muligheder for juridisk bindende internationale forpligtelser. Og uden USA's deltagelse nytter det ikke. Dels fordi USA's bidrag til klimaændringerne er så stort, dels fordi uden et forpligtet USA vil ingen 
af de andre betydende udledere forpligte sig til andet end bagateller.

Konklusionen er da heller ikke overraskende. Dagens globale emission af drivhusgasser er i bedste fald kun marginalt lavere, end hvad det ville have været uden Rio-konferencens klimadel. Andre forhold som billig gas i Nordamerika eller recessionen har haft større indflydelse på $\mathrm{CO}_{2}$-emissionen end klimapolitikken. Det var ikke, hvad vi forestillede os i 1992.

\section{EU's rolle}

Det er den almindelige opfattelse, at EU har været frontkæmper i de internationale bestræbelser for ambitiøs klimapolitik. Det er en overvurdering. Det lykkedes Kommissionen og efterfølgende regeringscheferne i 2008 at 'sælge' EU's 20-20-20 målsætninger som ambitiøse trods det forhold, at EU allerede i 2008 var tæt på at opfylde 20 procent emissionsreduktion (takket være bl.a. udvidelsen i 2004 og flittig brug af kvotekreditsystemet CDM). Recessionen medførte, at 20 procent målet allerede var nået i 2009(!), uden at det efterfølgende har været muligt for Kommissionen at fremlægge et forslag, der tager højde for denne udvikling.

Samme forhold afspejler sig i $\mathrm{CO}_{2}$-kvotesystemets sammenbrud, hvor kvoteprisen nu er så lav, at den har mistet enhver betydning som prissignal eller 'driver' af en grøn omstilling af energisektoren.

Manglende enighed mellem nøglespillerne og fraværet af en mere aggressiv klimadagsorden i EU er tilstrækkeligt til at blive mismodig over udsigten for de kommende års internationale klimapolitik. Hertil kommer så yderligere det forhold, at de grønne organisationer har svigtet deres egentlige opgave. Snarere end at forsøge at finde konstruktive veje til en bedre klimapolitik, fx Klimakonventionens krav om gennemførelse af konkrete 'policies and measures', har de insisteret på at køre længere ind i den blindgyde, der hedder Kyoto-sporet. Det er måske godt for deres image, men ikke for klimaet.

En rapport fra det hollandske Environmental Assessment Agency (PBL) viser, at da man i $1997 \mathrm{blev}$ enige om, at Annex-1 landene (industrilandene) kollektivt skulle reducere deres emissioner med 5,2 procent omkring 2010 i forhold til 1990, var dette 'reduktionsmål' allerede opnået i kraft af det voldsomme fald i emissionerne i Rusland og $\emptyset$ steuropa efter socialismens sammenbrud. Kyoto-protokollen åbnede således for mulighed for en (beskeden) stigning i Annex-1 landenes kollektive emissioner frem mod 2010. Det var ikke et synspunkt, man gjorde karriere på at fremføre, hverken som politiker eller embedsmand. Det fremgår også af rapporten, at de faktiske udslip fra de resterende KP-lande har været en del 
lavere end reduktionsmålet, siden USA i 2001 forlod KP. Alt det efterfølgende postyr om at få Rusland til at ratificere for at KP kunne træde i kraft har været fuldstændig uden betydning for drivhusgasemissionen.

Det er ikke overraskende, at atmosfærens $\mathrm{CO}_{2}$-indhold stiger år for år. $\mathrm{Nu}$ tættere på 2 ppm per år snarere end de $1,5 \mathrm{ppm}$, vi registrerede for 20 år siden.

\section{Biodiversitetskonventionen (CBD)}

Biodiversitet er en langt mere kompliceret sag end klimaet. Drivhusgasemissioner og global temperaturstigning evt. suppleret med vandstandsstigninger og hyppigheden af ekstreme vejrsituationer er få og letforståelige indikatorer på, hvordan det går med klimaet. Anderledes med biodiversiteten. Skal den måles på, hvor mange arter der årligt forsvinder, og er de alle lige værdifulde? Eller handler det snarere om udviklingen i levesteder for vilde dyr og planter, antal og/eller kvalitet? Hertil kommer, at der allerede før 1992 fandtes et antal internationale aftaler, fx Ramsar-konventionen om beskyttelse af vådområder af betydning for fuglelivet eller CITES-konventionen, der regulerer den internationale handel med truede dyreog plantearter. Det er næppe muligt at adskille virkningen af de forskellige aftaler på den globale biodiversitet.

Der er imidlertid ingen tvivl om, at biodiversitet i langt højere grad end tidligere 'kom på dagsordenen' ved Rio-konferencen i 1992. Men det var en meget svær fødsel. Det tog lang tid at få etableret et dueligt sekretariat for konventionen, og USA har aldrig ratificeret CBD. Der er bred enighed om, at 1990'ernes målsætning om at standse tilbagegangen i biodiversitet i 2010 ikke er nået. Hverken tropeskovene, fiskebestandene eller koralrevene er blevet stabiliseret, og befolkningstilvækst og stærkt tiltrængt økonomisk udvikling i mange ulande udgør et stadigt, ofte ukontrolleret, pres på biodiversiteten de pågældende steder.

Det er efterhånden bredt accepteret, at det er truslen mod dyrenes og planternes levesteder, der er det helt afgørende problem, men det er også præcis her, presset er størst. Behovet for at forøge fødevareproduktionen til en stigende og ikke mindst mere krævende global befolkning er og vil fortsat være den største hindring for at opfylde CBD's overordnede målsætninger. Klimapolitikkens begejstring for biobrændstoffer og anden biomasse (bortset fra det der kommer fra affaldsprodukter) øger dette problem.

Også truslen fra invasive fremmede arter er et problem, som truer biodiversiteten mange steder, uden at der internationalt er udarbejdet de nødvendige forholdsregler.

Det er vigtigt at være opmærksom på fundamentale forskelle mellem 
klimakonventionen UNFCCC og biodiversitetskonventionen CBD.

CBD er i langt højere grad end UNFCCC en platform, hvor parterne kommer sammen for at udveksle erfaringer, inspirere og diskutere mulige strategier inden for konventionens området. Hvor det er svært at identificere fremskridt i den globale klimapolitik siden 1992, er der mere liv i biodiversitetssamarbejdet. Cartagena-protokollen om 'biosafety' og den efterfølgende protokol om adgang til og fordeling af fordelene ved udnyttelsen af genetiske ressourcer demonstrerer dette. De strategipapirer, der blev vedtaget på den 10. partskonference i Japan i 2010, skal også ses i det lys. De er, mere end bindende krav, anbefalinger af, hvad parterne bør gøre for at opfylde deres forpligtelser under konventionen. Man kan, lidt efter temperament, glæde sig over den 'operationalisering', der ligger i 2010-beslutningerne, eller frustreres over, at der skulle gå næsten 20 år efter konventionens vedtagelse, før dette skridt blev nået. Desværre på baggrund af en erkendelse af, at de oprindelige mål om at standse nedgangen i biodiversiteten ikke var nået.

For begge konventioners vedkommende synes det at gælde, at det reelle fremskridt beror på, hvad de 'store' parter vil. Konventionstekster får ikke kineserne til at afvikle kulforbruget, amerikanerne til at opgive firehjulstrækkerne eller Brasilien til at standse afskovningen i Amazonas. Biodiversitets-samfundet har været bedre til at erkende dette end klimapolitikerne. Set i bakspejlet var det en fejltagelse, når man (vi) havde så travlt med at komme videre fra UNFCCC til KP, en fejltagelse der burde have været undgået, efter at det blev klart, at Clinton/Gore-administrationen ikke var i stand til at få kongressen med på den plan, der skulle have implementeret USA's forpligtelser under UNFCCC.

Det globale klima ville givetvis have været bedre tjent med, at man havde brugt kræfterne på at omsætte forpligtelserne i UNFCCC til virkelighed, fremfor at EU, ulandene og de grønne organisationer brugte kræfterne på at presse USA til en aftale, der, selv hvis præsidentvalget i 2000 havde sendt Al Gore til Det Hvide Hus, alligevel ville være strandet i Kongressen (Senatet). Der kan mobiliseres undskyldninger for denne fejlvurdering. Disse undskyldninger gjaldt ikke længere, da man gentog øvelsen op til COP15, og det er helt katastrofalt, at man nu, med beslutningen på COP17 i Durban i december 2011, har sikret, at denne håbløse fremmarch fortsætter.

\section{Agenda 21}

Både UNFCCC og CBD blev i virkeligheden forhandlet uafhængigt af forberedelsen til Rio-konferencen, og begge konventioner var færdigforhandlet før mødet i Rio. Stats- og 
regeringschefernes eneste indsats var at skrive under på den stiplede linje, og det kan med en vis ret hævdes, at konventionerne, Rio-konference eller ej, under alle omstændigheder ville være kommet til verden. Det egentlige Rio-dokument, Agenda 21, er derimod den direkte og generelle opfølgning på Brundtland-kommissionens rapport om bæredygtig udvikling. Dokumentet, der foregiver at sætte dagsordenen for det 21. århundrede, er på 300 sider fordelt på 40 kapitler med så forskellige emner som 'ændrede forbrugsmønstre', 'bekæmpelse af afskovning', 'fremme af bæredygtigt landbrug', 'beskyttelse af kvaliteten og forsyningen af ferskvandsressourcer', 'børn og unge i bæredygtig udvikling' og 'International Institutional Arrangements'.

Det siger sig selv, at det langsigtede resultat af 300 siders meget forskelligartede anbefalinger ikke lader sig gøre op i få sætninger, og vurderingen vil givetvis afhænge af, hvem man spørger. Men i det store og hele kan man konstatere, at Agenda 21 kun har haft beskeden indflydelse på politikformuleringen efter årtusindskiftet. Som det nødvendigvis må gå med arbejde, der forsøger at anvise en langsigtet strategi (jfr. Klimakommissionens rapport fra 2010): Man må være tilfreds, hvis de gode ideer kan påvirke politikformuleringen umiddelbart efter offentliggørelse af visionen, men selvfølgelig er der ingen, der i dag ville søge vejledning i Agenda 21's afsnit om 'styrkelse af arbejdernes og fagforeningernes rolle', når det kommer til politikformulering om bæredygtig udvikling. Ikke en gang fagforeningerne.

En egentlig evaluering af, i hvilken grad målene i Agenda 21 er blevet opfyldt, er en omfattende proces og ville i øvrigt kræve et langt bredere forfatterskab. UNEP, FN's miljøorganisation, har imidlertid for nylig forsøgt at evaluere, i hvilken grad de 100 mest betydningsfulde miljømålsætninger fra de seneste årtier er blevet opfyldt, og resultatet er nedslående. Kun fire når i mål, og langt de fleste er meget langt bag efter, hvad der blev satset på. Det er desværre det generelle billede.

På den positive side (ud over eliminering af bly i benzin og genopbygning af ozonlaget) er der imidlertid to vigtige og tilsyneladende varige resultater af Rio-mødet. Det første er, at miljøbeskyttelse kom på dagsordenen i mange udviklingslande. Ikke nødvendigvis så stærkt, at det sikrede bæredygtig udvikling, men det gjorde miljøpolitikken heller ikke i den industrialiserede verden efter Stockholm-konferencen i 1972, der på tilsvarende vis gav stødet til disse landes miljøadministrationer og miljølovgivning.

Verdensbanken, der jo ellers ikke har været berømt for høj miljøprofil, gjorde en betydelig indsats ved at bistå ulandene med at udarbejde nationale miljøhandlingsplaner. Des- 
værre var der ikke en tilsvarende erkendelse af behovet for at oprette tilstrækkelig magtfulde institutioner eller bevilge de nødvendige ressourcer til at sikre, at planerne blev ført ud i livet, og det må konstateres, at det er få lande uden for den lille, 'frelste' gruppe, hvor bæredygtigheden her 20 år efter rangerer på niveau med den økonomiske udvikling.

Det andet område, hvor Rio-konferencen satte noget i gang, var de lokale Agenda 21-planer (kapitel 28: 'Lokale myndigheders initiativer til støtte for Agenda 21'). Årene efter 1992 så en lavine af kommunale initiativer ('Sustainable Cities' og byer, der forpligtede sig til 20 procent $\mathrm{CO}_{2}$-reduktion i 2000 m.m.), i starten især i Europa, men efterhånden som den amerikanske regering viste sig ude af stand til at gennemføre en progressiv klimapolitik også i USA. Mange af disse initiativer lever stadig; adskillige, ikke mindst i Danmark, i bedste velgående.

Man skal ikke være blind for, at en række af disse initiativer i høj grad har været drevet af ønsket om at fremtræde med grøn profil snarere end et dybfølt engagement i bæredygtig udvikling. Imidlertid er initiativerne vigtige, fordi de meget direkte afspejler en prioritet hos brede vælgergrupper og dermed udøver betydeligt pres på regeringer, der ellers ville foretrække at imødekomme diverse økonomiske interessenters ønsker.

\section{Rio+20?}

Når disse linjer skrives, er stats- og regeringscheferne på vej til Rio. Nogle fra G-20 mødet i Mexico, andre fra deres respektive hovedstæder - og andre overhovedet ikke. De sidste fortjener ikke mindre respekt end de første, selv om deres motiver for at blive væk ikke nødvendigvis er de ædleste. Det lyder måske arrogant, men sagen er, at det er næsten umuligt at forestille sig, at det vil komme til at spille nogen som helst rolle for den fremtidige bæredygtighed, hvad der kommer til at stå $\mathrm{i}$ slutdokumentet fra Rio+20.

Behovet for en indsats for bæredygtig udvikling er større i dag end for 20 år siden. Men villigheden er mindre. Det forhold, at USA i de sidste 20 år enten ikke har villet (Bush/Cheney) eller ikke har kunnet (Clinton/Gore og Obama) levere blot et beskedent bidrag til bæredygtigheden af den globale udvikling, har lammet processen. Det forhold, at andre OECD-lande, bl.a. Canada og Australien, har lagt sig tæt op ad USA, har betydet, at industrilandene har været afskåret fra at fremtræde med bare noget, der ligner en fælles progressiv dagsorden. EU forsøger godt nok at se progressive ud, men det mangler overbevisning. Den nærmest totale lammelse af klimapolitikken, det udvandede forlig om energieffektivitet eller den fortsatte subsidiering af landbruget tjener som eksempler på afstanden 
mellem, hvad EU siger, og hvad EU gør. Hertil kommer, at Rio+20 aldeles mangler det momentum, som Brundtland-rapporten leverede i 1992.

Ulandene deltager i Rio+20 med megen skepsis. Det er velbegrundet. Det er ikke svært at finde graverende eksempler på korruption og hykleri i mange ulande. For hykleriets vedkommende er det imidlertid lettere at forsvare ulandenes hykleri end i-landenes. De sidste 20 år har været præget af brudte løfter og ubegrundede krav. Da Hillary Clinton som USA's udenrigsminister var i Indien forud for COP15 for at overtale den indiske regering til at påtage sig bindende forpligtelser $\mathrm{i}$ en kommende klimaaftale, blev hun helt berettiget sendt hjem af den indiske miljøminister med besked om, at så længe Indiens per capita emission var mindre end 10 procent af USA's, kunne hun starte med at feje for egen dør.

Og var der ikke en 'case' for nogle år siden, hvor Danmark kreativt brugte af allerede afsatte ulandsmidler til at dække en klimaforpligtelse, der helt klart var aftalt at skulle komme fra nye midler? Eller, som en ikke-EU-præsident engang sagde, da han blev klandret for sit lands omfattende korruption: "Fra hvilket sprog kommer ordet 'mafia' egentlig?"

De grønne organisationer må påtage sig en del af skylden for de ringe resultater. Ikke sådan at forstå at de grønne organisationers indsats skal underkendes. Men hvor det i 1992 var vigtigt at sige de rigtige ting og støtte Brundtland-kommissionens rapport, drejer det sig i dag i langt højere grad om at nå konkrete resultater end om at have ret. Denne mangel på erkendelse af en ny dagsorden er særlig markant på klimaområdet. I stedet for at glæde sig over, at alverdens lande er blevet enige om to graders målsætning, og derefter se det som hovedopgaven at få skabt enighed om maks. 1,5 grads temperaturstigning, burde de grønne organisationer have underkendt de fuldstændig tomme tilsagn fra COP15, -16 og -17 og insisteret på, at aftalen om, at klimaforhandlingerne i 2015 skal fastlægge mål for 2020, er det rene bluff. Hvad det er, hverken mere eller mindre. Der synes at være opstået en u-hellig alliance mellem de grønne organisationer og et antal regeringer båret af at prioritere det grønne image over ønsket om konkrete fremskridt. I modsat fald ville parterne for længst være vendt tilbage til UNFCCC's juridisk bindende forpligtelser for industrilandene til at gøre noget ved sagen.

En anden, ikke mindre, svaghed i de globale bestræbelser på at sikre bæredygtig udvikling er, at opgaven fra starten blev overdraget til miljøministrene frem for til finansministrene, hvor den rettelig hører hjemme. Ingen steder i verden har miljøministrene haft mulighed for 
at sætte sig igennem over for de kolleger, der varetager landbrugs-, transport-, energi- eller industriinteresserne. Hvis Danmark havde ment det alvorligt med bæredygtig udvikling, ville delegationen til Rio have bestået af Bjarne Corydon som delegationsleder, Margrethe Vestager som vice ditto, og herudover Mette Gjerskov, Henrik Dam Kristensen og Martin Lidegaard (som energiminister). Det eneste der taler mod denne sammensætning er, at de pågældende ville få svært ved at finde deres tilsvarende kolleger fra de andre lande. Det ser ikke godt ud med bestræbelserne på at integrere miljøhensynene i de økonomiske politikområder, selv om behovet har været anerkendt, allerede før Brundtland-kommissionen gik i gang.

\section{Efterskrift}

Efter afslutningen på dette indlæg kom slutdokumentet fra Rio+20. Det bekræfter stort set synspunkterne ovenfor. Det er beskæmmende, at man så skamløst gentager analysen af, hvad der er behov for. Det adskiller sig ikke meget fra 1992, uden i realiteten at give det mindste bud på, hvad man vil gøre ved det. Og det er beskæmmende, at deltagerne, især politikerne, forsøger at strø sukker ud over situationen ved at tale om, at 'det var det bedste, der kunne opnås', eller 'et godt grundlag for at finde løsninger'.

Det er almindeligt at hævde, at en utilstrækkelig aftale er bedre end ingen aftale. Det er ikke rigtigt. En utilstrækkelig aftale fjerner behovet for at finde alternative løsninger og leverer et alibi for at fortsætte elendigheden. Klimaforhandlingerne har leveret et overbevisende eksempel på dette. Rio+20 forsætter trenden.

Jørgen Henningsen kom i 1987 til Europa-Kommissionens Generaldirektorat for Miljøbeskyttelse som direktør med ansuar for bl.a. globale miljøproblemer. Han var Kommissionens chefforhandler for Klimakonventionen (UNFCCC) og Kyoto-protokollen. Han deltog i Rio-konferencen i 1992 og $i$ Rio+10 i Johannesburg 2002. Han var fra 2008 til 2010 medlem af regeringens Klimakommission og er nu tilknyttet tanketanken CONCITO. 